\title{
Systemic Failure in US Capital Markets: Lessons Not Learned
}

\author{
By Susanne Trimbath ${ }^{*}$
}

\begin{abstract}
Existing intellectual frameworks for the financial stability that leads to prosperity could have prevented the systemic failure that led to the 2008 collapse of global capital markets. This analytical article demonstrates the point by applying two well known frameworks to financial regulation in the US. This approach provides a characterization of the relationship between financial infrastructure and financial market stability that is well aligned with existing theory about stable financial systems. The author finds that the United States failed to provide a systemically prudent framework in any of the primary policy areas identified by Barth et al. (2004) through their analysis of World Bank surveys. Further, US financial regulators failed to fulfill the key tasks identified by Eatwell (2001) in a comprehensive examination of the regulatory factors that contribute to financial stability. The author concludes that economically efficient specialization in financial services would release economic gains from comparative advantage.
\end{abstract}

Keywords: Capital markets, Economic development, Financial regulation, Globalization, International debt crisis.

\section{Introduction}

Existing frameworks for regulating financial systems could have prevented the systemic failure in the United States (US) that led to the collapse of global capital markets in $2008^{1}$. The approach in this article is to generate a characterization of the relationship between financial infrastructure and financial markets that follows research based on World Bank survey data plus the work of Lord John Eatwell, Director of the Cambridge Endowment for Research in Finance and President of Queen's College. Our approach puts the 2008 events into perspective by examining them in the intellectual context of what we know and understand about building, developing and maintaining stable financial systems. A global financial crisis does not present an opportunity, as Allen and Carletti (2011) and others have suggested, for investing in new theories. Cancelling decades' worth of study and analysis because a crisis has come home to the place where much of that research was conducted would be "throwing the baby out with the bathwater". Granted, the recent crisis severely impacted countries that were believed to be fulfilling the requirements for a robust regulatory framework. However, we demonstrate that

\footnotetext{
* CEO and Chief Economist, STP Advisory Services, LLC, USA.

${ }^{1}$ The crisis began in 2007 and continued into 2009. We use "2008" for simplicity. A special section in the Journal of Applied Corporate Finance (Spring 1991), contains 5 papers on different sides of the debate over dating credit cycles.
} 
the problems were more likely in the definitions and measurements used to apply the theories than in the theories themselves.

\section{Four Policies and Five Tasks}

With the Asian financial crisis of 1997, the international financial system entered a new era in which cross-border risks would spread faster than ever: "The potential economy-wide inefficiency of liberalised financial markets was indisputable" (Eatwell 2001). In a summary of work advocating for an international financial authority, Eatwell specified the main tasks to be performed by national financial regulators that are seminal to stable global markets. Independently, the World Bank compiled the results of a first-ever global survey, completed in 1999, on bank regulation and supervision. Working with that data, Barth et al. (2004) began establishing a comprehensive framework for financial system regulation that they could demonstrate as important for stability. Based on their work, we summarize four primary policies and five key tasks that have been shown to promote stable financial systems that support healthy capital markets ${ }^{1}$. We begin with the policies first published at the World Bank before addressing the financial regulators' tasks.

\section{Four Missing Policies}

Barth et al. (2004, henceforth "BCL") acknowledged that the US deposit insurance scheme set-up the moral-hazard problem and "continue[d] to be a concern" in 2001. Their conclusion, that the safety net should not prevent depositors and taxpayers from holding banks accountable for their actions, played out across several actions of the US government during the 2008 crisis. The other three policies - minimized government ownership, independent credit rating agencies and allowing banks to dabble in a broad range of investments - were just as central to the crisis. ${ }^{2}$

Barth et al. (2013) acknowledge that "measuring bank regulation and supervision around the world is hard". By necessity, some regulatory measures from the World Bank survey entered the BCL analysis as discrete or binary variables. BCL attempted to overcome some problems by constructing indexes in order to synthesize responses into a manageable database ${ }^{3}$. More granular data might capture the nuances of a national government's willingness to

\footnotetext{
${ }^{1}$ The 4 policies and 5 tasks were first summarized in Trimbath (2004). A more recent, nonacademic summary that included a brief discussion of specialization, appeared online as "10 Steps to Financial System Stability: Lessons Not Learned" by Susanne Trimbath, NewGeography.com, 20 November 2014. A somewhat longer working paper is available from SSRN.com or Researchgate.net. A significantly longer exposition of the 10 steps, including references to non-financial and non-academic theories, is available in Trimbath (2015).

${ }^{2}$ See BCL and Barth et al. (2001) for complete coverage of the theoretical and empirical literature on these four important points.

${ }^{3}$ See Barth et al. (2001) and (2013) for details on the construction and contents of the indexes they used.
} 
support unstable financial institutions. In the following sections, we address the four policies in turn.

\section{Limited Safety Net}

When BCL wrote about "limiting the adverse incentive effects from generous deposit insurance" the definition of "generous" was significantly different than it would become by the end of 2008. From 1980 until October 2008, the limit of the US Federal Deposit Insurance Corporation (FDIC) was $\$ 100,000$. In October 2008, Congress more than doubled the limit to $\$ 250,000$. From the time the Dodd-Frank Wall Street Reform and Consumer Protection Act (DFA) was signed into law (July 21, 2010) through the end of 2012, the FDIC "provided unlimited deposit insurance" (emphasis added, Berson and Berson 2012).

Exactly this problem has caused consternation for many researchers; the Bank for International Settlements (2011) lists "ex post versus ex ante availability of official liquidity" among the technical issues that complicate assessments. The FDIC limit is measured "per depository, per insured bank, for each account ownership category". This definition makes it possible for a depositor to be reimbursed for twelve times the $\$ 250,000$ limit. "Ownership categories" include single, retirement, joint, and trust accounts all of which could be used by a family of four to achieve up to $\$ 3,000,000$ in coverage (FDIC 2013: 18).

In 2012, the year-end Deposit Insurance Fund (used to pay FDIC guarantees) fell to $\$ 22.7$ billion, a reserve ratio of just $0.32 \%$. This happened despite requiring banks to prepay 3 years worth of premiums in September 2009. DFA established a requirement for the fund to maintain a reserve ratio of at least $1.35 \%$. A proposal to meet the DFA requirement will not even be examined by FDIC staff until the reserve ratio reaches $1.15 \%$ which is not expected until the end of 2018 (FDIC 2012) - nearly a decade after the legislative requirement.

Measuring only the traditional safety net of deposit insurance ignores the virtually unlimited funding that governments are willing to provide to support the economy and its financial system in times of crisis (Seidman 1997). Beginning in October 2008, the US financial system was supported by the Emergency Economic Stabilization Act of 2008, by the US Treasury in the Troubled Assets Relief Program (TARP), by the Federal Reserve in the Term Asset-Backed Securities Loan Facility, etc. Bloomberg reporters Mark Pittman and Bob Ivry added up $\$ 12.8$ trillion in government financial rescue commitments through March 31, 2009. In fact, the conversion of brokers into banks established virtually overnight new systemically important entities with "too big to fail" status. Worse yet, allowing Lehman Brothers to fail in the months leading up to the bailout only amounted to the federal government picking winners and losers rather than the exercise of restraint advocated by $\mathrm{BCL}^{1}$. Furthermore, banks were not "held accountable". The Government

1 "Solving the Financial Crisis: Looking Beyond Simple Solutions" by Susanne Trimbath, 17 January 2009, NewGeography.com. 
Accountability Office (GAO) and the Special Inspector General for TAPR (SIG-TARP) reported that billions of dollars in loans made by the US Treasury and the Federal Reserve were not documented. The specter of corruption looms over the availability of data on these programs.

\section{Limited Government Ownership and Control}

The World Bank survey question analyzed by BCL for government ownership policy offered a limited choice of responses. The question was "What fraction of the banking system's assets is in banks that are 50\% or more government owned". Responses to this question could not consider the extent to which a government is willing to take ownership positions in exchange for financial support in times of crisis. The US government took ownership in all major financial institutions during the bailout, plus several industrial companies (GAO 2011). While General Motors and General Electric had financial arms (lending for consumer purchases), Harley Davidson and Target did not. Lending to non-regulated companies violated a congressional prohibition on Federal Reserve activities. To get around it, the Treasury Secretary in cooperation with the Chairman of the Federal Reserve exploited a loophole in the law by making loans through newly created "Limited Liability Companies". These programs required the recipients to relinquish some ownership to the government.

It might be argued that government participation in the greater economy through bailouts -including taking ownership stakes- could not have been foreseen. Historical facts paint a very different picture:

- In 1970, the commercial banks received assistance from the Federal Reserve to shore up their reserves after Penn Central Railroad declared bankruptcy.

- Also in the 1970s, Lockheed Corporation (now Lockheed Martin, a major contract supplier to the US military), Franklin National Bank (declared insolvent on 8 October 1974), and the city of New York received federal financial support (US\$1.4 billion, US\$7.8 billion and US\$9.4 billion, respectively).

- In the $1980 \mathrm{~s}$, Chrysler Motors ( $\$ 4.0$ billion), Continental Illinois National Bank ( $\$ 9.5$ billion), and the savings and loan industry (\$293.3 billion) received federal aid.

- After the terrorist attacks of September 11, 2001, the US airline industry received $\$ 5$ billion in compensation and $\$ 10$ billion in federal credit.

By providing financial support to banks and businesses alike "the Federal Reserve System stood ready to accept risks that the market participants were not willing to accept" (GAO 2011). As of June 30, 2012, the US Treasury still owned $61 \%$ of American International Group, Inc., ("AIG") common stock (SIG-TARP 2012). Because AIG was the world's largest insurance company, the US government owns not just national but also international financial 
companies -an ownership standard not captured by data available to BCL. In June 2015, Judge Thomas C. Wheeler of the United States Court of Federal Claims (Starr International v. The United States, Case No. 11-779C) determined that the Federal Reserve Bank of New York (FRBNY) did not have the legal authority to take ownership in AIG. Wheeler wrote that "there is nothing in the Federal Reserve Act or in any other federal statute that would permit a Federal Reserve Bank to take over a private corporation and run its business as if the Government were the owner. Yet, that is precisely what FRBNY did."

\section{Independent Rating Agencies}

The US rating agencies were only technically independent of government. The US Securities and Exchange Commission's (SEC's) designation of "Nationally Recognized Statistical Rating Organization" ("NRSRO") -and its proliferation across SEC rules and regulations- resulted in rating agencies that were perceived by financial markets as government-sanctioned if not quasigovernment. An NRSRO is a credit rating agency that the SEC accepted for use to meet certain regulatory requirements. Although credit rating agencies were mentioned in SEC regulations as far back as 1975, the "NRSRO" designation was codified with implementation of the Credit Rating Agency Reform Act of 2006 (CRARA). The statute-created NRSRO designation became a government imprimatur which created undue reliance on ratings by participants in financial markets (SEC 2012ba). Within a few years of its creation, the term "NRSRO" could be found in more than a dozen SEC rules and forms (excluding those directly related to NRSROs registration and regulation) plus the securities industry rules in individual states and the selfregulatory organizations that populate US and international financial systems (Buckholz et al. 2009). US rating agencies lost their "technical" independence in the sense that they were now "authorized" or "sanctioned for use" by the Executive Branch of the federal government.

The NRSRO designation created a barrier to entry with the potential to restrict competition, giving additional power to the producers/sellers of credit ratings. Two firms had a virtual monopoly on the rating industry, with the three largest firms (Moody's, Standard \& Poor's and Fitch) issuing 98\% of all outstanding credit ratings (Casey 2009). The standard four-firm concentration ratio reaches critical value at $50 \%$, after which the industry is a monopoly, with non-contestable markets in which prices are easily controlled (Magee and Magee 2008). According to BCL, such barriers to entry into financial markets "are positively associated with government corruption".

The CRARA specifically prohibited the SEC from regulating an NRSRO's methodologies. This created the conditions whereby the SEC sanctioned the NRSROs and required the use of their ratings but the SEC had no control over the process. Despite even pseudo-independence from government regulators, the NRSROs did not have independence from the financial institutions that paid them for ratings. Gaining sanction from the SEC gave the rating agencies more power to wield against -or in favor of- securities issuers. When damning, 
internal emails surfaced during a congressional investigation into the 2008 crisis, former managing director at Standard and Poor's Frank Raiter spoke out to the media saying, "During this period, profit was primary. Analytics were secondary." 1

DFA gave the SEC the power to regulate NRSRO internal processes regarding record-keeping and how they guard against the conflicts of interest which were determined (by several sources) to be a contributing factor to the 2008 crisis. SEC data reveals that since 2011, 171 rating agency staff reported taking jobs with banks and other bond issuers within twelve months of exercising decision making authority over ratings assignments for the same institutions. A statistical analysis by Griffin and Tang (2012) found that securities rated AAA between 1997 and 2007 should on average have been rated BBB by the rating agencies' models and standards. Higher NRSRO credit ratings result in higher market prices (valuations) for securities; the difference identified by Griffin and Tang demonstrates over-pricing (in favor of the issuer) of $20.1 \%$. A 2008 audit of several NRSROs reported that they regulatory reduced the loss expectation inputs to their ratings models without supporting documentation (SEC-OCIE 2008).

\section{Diversified Services and Investments}

The questions about the range of services offered by capital market participants had significantly more granularity than some of the others. Regarding bank activities in securities, insurance and real estate, BCL created an index in each area for unrestricted, permitted, restricted or prohibited (Table 1 in BCL).

The wide range of activities allowable in the years leading up to 2008 indisputably increased volatility. Risk was concentrated instead of dispersed, which would be the purpose of diversify an investment portfolio. Indeed, we argue below that more specialization can lead to greater economic efficiencies, regardless of the financial theory that supports diversification by banks. There is a key difference between diversifying investments and trying to be all things to all people. The so-called Volker Rule (12 USC §1851, nee DFA §619) would prohibit banks from investing in hedge funds, but not from making investments to hedge genuine business risk (Berson and Berson 2012). It can easily be understood as the difference between what banks invest in and what products and services banks offer to their customers.

DFA ended the federal requirement that banks buy securities defined as investment grade by NRSROs. Credit ratings were referenced by the Federal Reserve in nine general risk-based rules, a market risk rule, 23 advanced approaches rules (risk-based capital framework) and 13 other Board regulations (FRB 2011). It is possible that the requirement limiting certain bank and pension fund investments to "AAA-rate" securities could have attributed to the "pay for play" attitude between the NRSROs and the financial institutions. We now know that these ratings were given to some very risky and

\footnotetext{
${ }^{1}$ NOW on PBS, December 26, 2008, "Credit and Credibility".
} 
potentially dangerous investments. DFA $(\$ 165(b))$ mandates certain capital requirements to help banks manage the risks associated with investments. This new mandate aligns with the findings in BCL on risk management in financial institutions.

It is not our purpose here to resolve how to regulate credit worthiness in the future, but only to demonstrate that the process followed in the US in the years (even decades) leading up to 2008 was not one that would meet the BCL definition of "unrestricted". Yet, it allowed banks to take enormous risks that led to the systemic failure of 2008 .

\section{Tasks Not Taken}

\section{Information and Standards}

Some of the tasks in Eatwell's list of tasks necessary for a coherent national regulatory structure also appear in BCL. For example, Eatwell stresses regulation and supervision which limit moral hazard and force accurate information disclosure in order to "critically boost bank performance stability". BCL also include a requirement for "accurate information disclosure" but with the goal of providing market transparency. For Eatwell, it is not just the ideal of transparency "but also common standards of information to support the efficient operation of international financial markets".

The failure to fulfill this task was perhaps nowhere more evident during the 2008 crisis than in the market for derivatives. As SEC Director of Financial Markets and Community Investment Orice Williams (2009) testified before Congress: "The gaps in the regulatory oversight structure of and regulations governing financial products such as CDS [credit default swaps] allowed these derivatives to grow unconstrained, and little analysis was done on the potential systemic risk created by their use". Just as there were no standards for derivatives, the securitization of a variety of debt instruments -most notoriously mortgages- did not adhere to any standards. When mortgage-backed securities (MBS) were issued, many contained no provision for reporting to land offices (county-level property offices in the US) about changes in liens from the originating bank to the purchaser (or issuer) of the MBS. Hence, in many cases, when a MBS investor attempted to foreclose on a property for payment delinquency, courts found insufficient documentation to support the MBS' lien on the property.

Without legally binding "receipts" of ownership, MBSs had insufficient real assets behind them. In one of the earliest court decisions on this issue, Cleveland District Judge Christopher Boyko (2007) dismissed a foreclosure complaint. In 2009, California District Bankruptcy Judge Samuel Bufford and former bankruptcy judge R. Glen Ayers revealed that not all MBSs were actually backed by mortgages: "A lawyer sophisticated in this area has speculated to one of the authors that perhaps a third of the notes "securitized" have been lost or destroyed" (Bufford and Ayers 2009). That suggests that 
approximately $\$ 3$ trillion of worthless mortgage bonds were issued by US financial entities and traded around the world ${ }^{1}$.

\section{Authorise Market Participants}

Once standards are set, Eatwell's next task is "ensuring that a business is financially viable, that it has suitable regulatory compliance procedures in place, and that the staff of the firm are fit and proper persons to conduct a financial services business". The US regulators notably failed to establish registration requirements for hedge funds and, perhaps most spectacularly, to close loopholes in the regulations which allowed insurance companies to issue credit default swaps in excess of existing prudent capital requirements by using subsidiaries not subject to supervisory oversight. Speaking directly to this issue, DFA established the Financial Stability Oversight Council to designate "Systemically Important Nonbank" entities already operating in the market. This "too big to fail" option may make matters worse by officially removing any limits set by deposit insurance.

Less well-known is the fact that before DFA the SEC did not have registration rules for municipal securities advisors (financial advisors to states and local governments) and solicitors hired by brokers/dealers "for the purpose of engaging a municipal entity or obligated person for or in connection with municipal financial products, or engaging an investment adviser to provide investment advisory services to or on behalf of a municipal entity". Although the Municipal Securities Rulemaking Board was authorized by Congress in 1975 (Exchange Act $\S 15 \mathrm{~B}(\mathrm{~b})$ ) to issue rules for the municipal bond market, according to SEC (2012b) it was "not granted authority to enforce its rules". After the registration requirement for municipal advisors became effective (October 1, 2010) the SEC "received approximately 1,000 confirmed registrations of municipal advisors, including approximately 300 registered broker-dealers, as well as approximately 700 other firms". Therefore, more than two-thirds of municipal advisors were unregulated prior to the 2008 crisis and prior to the passage of DFA. Municipal advisors were at the heart of the spectacular financial failure of Orange County (California) in the 1990s; had changes been implemented at that time it may have prevented the Jefferson County bankruptcy (Alabama) a decade later.

\section{Surveillance}

Without standards for performance or regulatory authorization of all market participants, of course, there could be no surveillance by any regulator. The list of un-monitored capital market products and activities that left global financial markets vulnerable includes credit default swaps (Williams 2009), Exchange-Traded-Funds (Bradley et al. 2011) and trading in bonds (Trimbath 2011). Even where most of the largest, financial firms in the US were subject to some form of supervision it proved to be "inadequate and inconsistent" (Treasury 2009).

\footnotetext{
${ }^{1}$ Face amount estimated with market data from Securities Industry and Financial Markets Association.
} 
Today, even what we believe to be some of our most highly regulated and monitored financial markets -such as the market for common stocks- continue to produce significant volumes of activity off-exchange, ex-clearing and without surveillance (e.g., "dark pools"). Despite growing concern over unsettled trades remaining in the national clearing and settlement system as early as 2001, the National Securities Clearing Corporation (NSCC) did not include them (fail positions) in the formula for calculating deposits used to protect against "exposure to participants' unsettled portfolios" (SEC 2005). As a result, the NSCC's clearing fund was insufficient to cover the unsettled trades that accumulated as the crisis approached. The magnitude of the systemic risk is evident (Table 1). On July 18, 2012, NSCC was designated "systemically important" by the Financial Stability Oversight council (FSCOC). The FSCOC is careful to state that the designation does not "mean that a company is considered too big to fail" ${ }^{1}$. However, that is the general perception of capital market participants. The designation comes with "enhanced prudential standards and consolidated supervision".

Table 1. Fail Positions at NSCC in Excess of Clearing Fund, 1997-2011 (US\$000)

\begin{tabular}{|l|c|c|c|}
\hline Year & $\begin{array}{c}\text { Total Fail } \\
\text { Positions }\end{array}$ & $\begin{array}{c}\text { NSCC Clearing } \\
\text { Fund }\end{array}$ & $\begin{array}{c}\text { Obligations in excess of } \\
\text { Fund }\end{array}$ \\
\hline $\mathbf{2 0 0 1}$ & $3,796,512$ & $2,855,313$ & 941,199 \\
\hline $\mathbf{2 0 0 2}$ & $3,048,154$ & $2,284,040$ & 764,114 \\
\hline $\mathbf{2 0 0 3}$ & $6,050,934$ & $2,468,774$ & $3,582,160$ \\
\hline $\mathbf{2 0 0 4}$ & $8,693,310$ & $2,740,088$ & $5,953,222$ \\
\hline $\mathbf{2 0 0 5}$ & $6,846,056$ & $2,639,734$ & $4,206,322$ \\
\hline $\mathbf{2 0 0 6}$ & $7,498,320$ & $2,952,164$ & $4,546,156$ \\
\hline $\mathbf{2 0 0 7}$ & $14,909,296$ & $4,866,576$ & $10,042,720$ \\
\hline
\end{tabular}

Source: Data compiled by author from National Securities Clearing Corporation annual financial statements. "Total Fails Positions" is the value of shares due to NSCC for trade settlement but not delivered by members in time for settlement, as of December 31 of Year; plus the value of shares covered in the Stock Borrow Program where shares are borrowed from Depository Trust Company members to fulfill some delivery failures at NSCC.

\section{Enforcement}

According to Eatwell (2001), surveillance and enforcement reside at "the operational heart of any effective regulatory system". Barth et al. (2013) reported that only 23 countries hold regulatory enforcement supervisors legally liable for their actions. In US capital markets, NSCC permits offenders who fail to deliver securities in time for settlement to maintain accounts without penalty. This is despite very specific language in the Securities Exchange Act of 1934 that "A registered clearing agency may summarily suspend and close the accounts of a participant who ... (ii) is in default of any delivery of funds or securities to the clearing agency"2. Similar problems occur in the market for

\footnotetext{
${ }^{1}$ The details of the FSCOC are beyond the scope of this article. For more information, see www.treasury.gov.

2 Section 17A National System for Clearance and Settlement of Securities Transactions (b)(5)(C); page 275 as amended through August 10, 2012.
} 
US Treasury securities. During the fall of 2008, in particular, the primary dealers sold more than $\$ 2.0$ trillion worth of bonds that could not be delivered to the buyers for eight weeks (based on data available from Federal Reserve Bank of New York). There was no enforcement of trade settlement.

Other than loan repayment, no consequences were established for any of the recipients of the bailout money described earlier. In the case of nonfinancial, non-regulated entities receiving Federal Reserve money, only standard contract law was available to enforce repayment. Although some civil-fraud trials went forward and some fines were levied, Justice Department prosecutors had put together only a few criminal cases through the end of 2012, mostly directed at fraud in the bailout programs. The statute of limitations for securities fraud in the US is a maximum of 5 years from violation. Therefore, any violations not prosecuted by 2013 would be barred from the courts.

We must conclude that even where codes existed to prevent some of the activities that lead to the crisis, they were not enforced. When sellers are allowed to create an infinite supply of financial instruments by selling more than they can deliver without penalty then security prices are not being set in efficient markets. According to the SIG-TARP (2012) report to Congress, the US Treasury has been selling some TARP investments at a loss to taxpayers, "sometimes selling its investment back to the bank itself" allowing even those banks who recovered financially to get out of the program for less than they owe.

\section{Keep the Regulatory Code Up to Date}

Here Eatwell emphasizes the importance of the policy function, especially "as new products are developed that transcend international boundaries". Brooksley Born, chair of the Commodity Futures Trading Commission (CTFC) from 1996 to 1999, raised enormous concerns over derivatives activity in the US during her tenure. Ms Born attempted to maintain regulatory codes in synchronization with financial innovation. Both the SEC and the Federal Reserve objected to regulation over derivatives. In 1999, the US Congress passed legislation that prohibited the regulation of derivatives. The result was a long period of growth in the unregulated market which can be directly connected to the 2008 crisis, where the use of credit default swaps and mortgage-related derivatives continues to bring new costs to major US financial institutions in the form of fines and legal fees. Even now, though DFA requires some derivatives investment advisors to register with the SEC, there are a multitude of exemptions (Berson and Berson 2012). According to SIG-TARP (2012), perhaps the largest financial/nonfinancial institution at the center of the crisis, AIG, would "once again" be subject to no financial regulation over issuing derivatives, which it continues to do. At the same time, AIG was notified that it was under consideration for designation as a systemically important financial institution, which they received on July 8, 2013. 


\section{Discussion}

Strong regulation and supervision alone cannot mitigate the moral hazard produced by violating any of the four policies: holding financial market participants accountable while protecting investors, limiting government control over economic assets to remove opportunities for profitable corruption, empowering the private sector to monitor financial market participants and then allowing banks -in an efficient, competitive market- to manage their businesses prudently. BCL demonstrated the four policies to be more important for economic growth and financial stability than legal tradition or media openness.

We also must ensure that financial regulators attend to the policy functions that drive effective regulation by authorizing participation in financial products, assuring the disclosure of accurate, standardized information, monitoring the adherence of financial participants to rules of good behavior through surveillance and enforcement, and keeping policies up to date with financial innovations. We cannot expect things to change if the US continues to use "a patchwork response to crises rather than [a] rational response" to the growth of systemic risk (Eatwell 2001: 17). Eatwell emphasizes the coevolutionary development of "theory and policy that link microeconomic risktaking to the macroeconomic propagation of systems risk". DFA is not the solution. It was passed before the Financial Crisis Inquiry Commission (FCIC) completed their investigation and reported on what happened and how it happened. Implementation has been slow and unimpressive (GAO 2013) ${ }^{1}$. Of the nearly 400 DFA rulemaking deadlines already passed (2015Q1), only 60\% have been met.

Creating new theories is not the way forward. Rather we need to strive to align policy and practice with good theory. New policies must shift the focus away from limiting or expanding the specific instruments that financial institutions can invest in, and focus on the factors that make domestic implementation of financial reform different from cross-border (Trimbath 2004). That each country is so different on each of these points may, in fact, prohibit complete alignment of global financial regulations.

The emerging market economies of Asia threatened the stability of the developed economies of the West in 1998 (Eatwell 2001). But in 2008, the largest developed economy was the source of a new threat to global economic stability. To avoid the next crisis, regulators and the financial institutions they oversee should turn to one very old lesson: specialization. Since Adam Smith's The Wealth of Nations in 1776, economists and businessmen alike have understood that specialization is the key to unleashing economic gains. Global equity markets are nearly US\$50 trillion in value with annual trading in the US alone measured in quadrillions (Depository Trust and Clearing Corporation 2014). Smith wrote that the size of the gains from specialization will increase

\footnotetext{
${ }^{1}$ See http://www.sec.gov/spotlight/dodd-frank.shtml for the most recent information on the SEC's progress toward implementing DFA.
} 
with the size of the market within which specialization occurs. The gains from specialization in financial services may be enormous.

Peter Drucker (1993) also makes this point on specialization. He wrote that, while "diversification" is good for a portfolio of financial investments, it means "splintering" in large systems where it can destroy performance capacity. Financial institutions are tools to be used in furthering the efforts of the broader economy. The economic benefits of specialization have been lost on US financial regulators who continue to apply portfolio theory in an automatic manner to financial institutions, transforming "diversification" into a series of clichés. Drucker writes, "As with any tool, the more specialized its given task, the greater its performance capacity", and so the greater the potential for future crises if bank executives and their regulators fail to head the lesson of specialization.

\section{Conclusions}

Throughout modern history, economic expansion has been connected to the rise and expansion of the financial sector into every corner of life. Robust financial flows in capital markets are linked to robust economic activity. Greater efficiency in capital markets can lead directly to greater efficiency in industry (Trimbath 2002). Our economy, our livelihood and our well-being are inextricably related to finance at home and around the world.

We do not pretend to explain the crisis, nor do we believe that these and only these missing tasks and policies were to blame -on this there can be no agreement. The Financial Crisis Inquiry Commission (FCIC) reviewed "millions of pages of documents, interviewed more than 700 witnesses, and held 19 days of public hearings" in the US. Four of the ten Commissioners dissented from the findings in the final report (FCIC 2011). They wrote two separate dissenting opinions -even the dissenters could not agree. It was our intention here to demonstrate that even these prudent, well-understand tasks and policies were not followed. Strong regulation and supervision were lacking in the US as the financial market collapse approached (FCIC 2011). The majority opinion of the FCIC concluded: "The captains of finance and the public stewards of our financial system ignored warnings and failed to question, understand, and manage evolving risks".

Long-term failure is not guaranteed for the US financial system or for global capital markets. The pieces were in place for a long time that allowed the systemic failure in 2008. In conclusion, we advocate for a change from ever-wider, ever-deeper financial services being offered in one institution in favor of the long run value of economically efficient specialization. We live in the post-capitalist society described by Drucker (1993). US regulators have been captivated by the financial theory of portfolio diversification for too long. Global financial systems suffer when regulators ignore the economic importance of comparative advantage and the gains that come through specialization. Drucker's post-capitalist society has arrived and financial 
institutions need to catch up to it by specializing. Drucker's 15-year old forecast came true in 2008: "Organizations can only do damage to themselves and to society if they tackle tasks that are beyond their specialized competence".

\section{References}

Allen F, Carletti E (2011) New theories to underpin financial reform. Journal of Financial Stability. doi:10.1016/j.jfs.2011.07.001.

BIS-Bank for International Settlements (2011) Global liquidity - concept, measurement and policy implications. Committee on the Global Financial System (CGFS) Papers No. 45 (November), Basel.

Barth JR, Caprio Jr, G, Levine R (BCL) (2004) Bank regulation and supervision: what works best. Journal of Financial Intermediation 12(April): 205-248.

Barth JR, Caprio Jr, G, Levine R (2001) Bank regulation and supervision: a new database. In R Litan, R Herring (Edn.). Brookings-Wharton Papers on Financial Services.

Barth JR, Caprio G, Levine R (2013) Bank Regulation and Supervision in 180 Countries from 1999 to 2011. Retrieved from http://goo.gl/PnCX27.

Bereson S, Berson D (2012) The Dodd-Frank Wall Street Reform and Consumer Protection Act - From Legislation to Implementation to Litigation. American Bar Association, Chicago.

Boyko CA (2007) Opinion and Order In Re Foreclosure Cases Number: 07cv2282, 07cv2532, 07cv2560, 07cv2602, 07cv2631, 07cv2638, 07cv2681, 07cv2695, 07cv2920, 07cv2930, 07cv2949, 07cv2950, 07cv3000, and 07cv3029. United States District Court, Northern District of Ohio, Eastern Division.

Bradley H, Fawls R, Litan RE, Sommers F (2011) Canaries in the Coal Mine: Systemic Risk for Financial Firms and Investors. Ewing Marion Kauffman Foundation Research Report (March). Retrieved from http://goo.gl/mB0mhh.

Buckholz Jr, RE, Harms DB, Wertheim F, Kadel Jr, EJ, Risoleo RS (2009) Use of Credit Ratings under the Investment Company Act of 1940. New York: Sullivan \& Cromwell LLP.

Bufford SL, Ayers RG (2009, April 3) Where's The Note, Who's the Holder: Enforcement of Promissory Note Secured by Real Estate. Washington, DC: Uniform Commercial Code Committee, American Bankruptcy Institute.

Casey KL (2009, September 17) Statement at SEC Open Meeting. Washington, DC: US Securities and Exchange Commission.

Depository Trust and Clearing Corporation (2014) 2013 Annual Report of the Depository Trust and Clearing Corporation. Retrieved from http://goo.gl/tgMJHx.

Drucker PF (1993) Post-Capitalist Society. New York: HarperCollins.

Eatwell J (2001) The Challenges Facing International Financial Regulation. Speech delivered at Financial Policy Forum, Derivatives Study Center Conference "The Economics of Financial Market Regulation" session at the Western Economics International Association San Francisco, California July 2001. Retrieved from http://goo.gl/hTymsh.

Eatwell J, Taylor L (1998) International capital markets and the future of economic policy. A paper prepared for the Ford Foundation project International Capital 
Markets and the Future of Economic Policy. New York: Center for Economic Policy Analysis. London: IPPR.

FDIC-Federal Deposit Insurance Corporations (2008) Temporary Liquidity Guarantee Program, Final Rule (12 CFR Part 370 RIN 3064-AD37). Federal Register 73(229, November 26): 72244-72273

FDIC-Federal Deposit Insurance Corporations (2013) Your Insured Deposits (brochure). Washington, DC. Retrieved from http://goo.gl/Xfzbc.

FRB-Federal Reserve System, Board of Governors (2011) Report to the Congress on Credit Ratings. Washington, DC.

FCIC-Financial Crisis Inquiry Commission (2011) Final Report of the National Commission on the Causes of the Financial and Economic Crisis in the United States (Pursuant to PL 111-21). Washington, DC: US Government Printing Office.

GAO-Government Accounting Office (2011) Federal Reserve System: Opportunities Exist to Strengthen Policies and Processes for Managing Emergency Assistance. GAO-11-696. Washington, DC.

GAO-Government Accounting Office (2013) Financial Regulatory Reform: Regulators Have Faced Challenges Finalizing Key Reforms and Unaddressed Areas Pose Potential Risks. GAO-13-195. Washington, DC.

Griffin JM, Tank DY (2012) Did subjectivity play a role in CDO credit ratings? Journal of Finance 67(4, August): 1293-1328

Magee CSP, Magee SP (2008) The United States is a Small Country in World Trade. Review of International Economics 16: 990-1004.

SEC-Securities and Exchange Commission (2005) Order Approving Proposed Rule Change to Modify and Consolidate Clearing Fund Rules [Self-Regulatory Organizations; National Securities Clearing Corporation]. Release No. 34-52772, File No. SR-NSCC-2005-13 (November 14). Washington, DC.

SEC-Securities and Exchange Commission (2012a, December). Report to Congress on Assigned Credit Ratings (As Required by Section 939F of the Dodd-Frank Wall Street Reform and Consumer Protection Act). Staff of the Division of Trading and Markets. Washington, DC.

SEC-Securities and Exchange Commission (2012b, July 31) Report on the Municipal Securities Market. Washington, DC.

SEC-OCIE-Securities and Exchange Commission Office of Compliance Inspections and Examinations (2008, July) Summary Report of Issues Identified in the Commission Staff's Examinations of Select Credit Rating Agencies. Washington, DC.

Seidman LW (1997) The world financial system: lessons learned and the challenges ahead (pp. 55-64) in FDIC (1997) History of the Eighties-Lessons for the Future. Division of Research and Statistics. Washington, DC. Retrieved from http://goo.gl/PQZ9aG.

SIG-TARP-Special Inspector General, Troubled Asset Relief Program (2012, July 25) AIG Remains in TARP as TARP's Largest Investment, Quarterly Report to Cngress. Washington, DC.

Trimbath S (2002) Mergers and Efficiency: Changes Across Time. New York: Kluwer Academic Press (Springer).

Trimbath S (2004) Promoting global financial development: Vive la différence! Progress in Development Studies 4(1): 65-76.

Trimbath S (2011) Trade settlement failures in US bond markets. IUP Journal of Financial Economics 9(1): 53-78. 
Trimbath S (2015) Lessons Not Learned: 10 Steps to Financial Stability. London: Spiramus Press, Ltd. (forthcoming, October 23).

US Department of the Treasury (Treasury) (2009) Financial Regulatory Reform, A New Foundation: Rebuilding Financial Supervision and Regulation. Washington, DC.

Williams OM (2009) Systemic Risk - Regulatory Oversight and Recent Initiatives to Address Risk Posed by Credit Default Swaps. Testimony Before the Subcommittee on Capital Markets, Insurance, and Government Sponsored Enterprises, GAO-09-397T (March 5). Washington, DC: United States Government Accountability Office. 
